\title{
The Catholic medical practitioner, family planning, and the Church
}

\section{William J LeMaire}

Professor Emeritus, Department of Obstetrics and Gynecology, The University of Miami Miller School of Medicine, Miami, $\mathrm{FL}$, USA

\section{Correspondence to} Professor William J LeMaire, Department of Obstetrics and Gynecology, The University of Miami Miller School of Medicine, 5751 SW 45 Terrace, Miami, FL 33155, USA: awlemaire@hotmail.com

Received 27 June 2014 Revised 18 August 2014 Accepted 13 September 2014 Published Online First 20 October 2014

\section{CrossMark}

To cite: LeMaire WJ. J Fam Plann Reprod Health Care 2015:41:24-26.

\section{BACKGROUND}

In daily practice, obstetricians and gynaecologists, family practitioners, midwives, nurses, nurse practitioners and physician assistants frequently deal with family planning issues. They commonly advise, prescribe, inject, insert and operate with the aim of preventing or interrupting fertilisation and conception. However, Roman Catholic practitioners are constantly faced with the dilemma between doing the right thing for their patients and the teachings of the Roman Catholic Church ('Church' for the remainder of this discussion), which opposes any artificial means of family planning and also abortion. ${ }^{1}$ Abortion will not be discussed here, as that issue would raise the argument to a different level.

The official position of the Church has been and still is that Catholics are not allowed to use any so-called artificial methods to prevent pregnancy. ${ }^{1}$ The Church considers the practice of any means of artificial intervention to be a grave sin. Catholic medical practitioners are equally prohibited from prescribing or carrying out such interventions, ${ }^{1}$ even though they may realise that doing so might be in the best interest of their patients.

In a simplistic way, this dilemma leaves Catholic practitioners with only two possible options: adhering to the teachings of the Church or following their own consciences. Following one's individual conscience is what the Church teaches anyway. $^{2}$

\section{ADHERING TO THE TEACHING OF THE CHURCH}

First, the medical practitioner may decide to abide by the teaching of the Church. However, in refusing to make available a wide range of contraceptive measures to their patients individuals will not be able to select what is perceived as being the most appropriate in their situation and make an informed choice. The practitioner will thereby be denying their patients a medical service that they may desperately need and want, and in fact may also be contributing indirectly to one of the world's most pressing problems, namely overpopulation. ${ }^{3}$

Overpopulation is at the source of, or at least contributes to, many of the currently most pressing global challenges. These include poverty, malnutrition and famine, crime, violence and armed conflicts, illiteracy, pollution and climate change. ${ }^{3}$ These problems have multiple causes and contributing factors, which may or may not be evident. Many of these challenges are dependent on the region in the world and may affect the developing world more than the developed world; however, the ramifications of overpopulation and its consequences are of concern to the whole world. Making affordable and effective methods of family planning available for all those requesting them is a positive step in reducing the problem of overpopulation.

The Church, in steadfastly opposing any artificial methods of family planning, may be contributing to the problem and is closing its eyes to some of the 'real' challenges facing our generation and those to come. Without a theological background, I am not in position to argue the Church's justification for the ban against all artificial means of family planning, but I can only address the practical consequences of this ban.

Authorities in demography have raised an opposite point of view, namely that the world faces a problem of an ageing population, and in the long run depopulation. ${ }^{4}$ I am also not in any position to argue with that viewpoint, but the most pressing current problem is still overpopulation, especially in certain areas of the world. Thus, by not providing patients with reliable methods for planning their own family, Catholic practitioners who follow the teaching of the Church may be derelict in their global responsibility. 


\section{MEDICAL PRACTITIONERS FOLLOWING THEIR} OWN CONSCIENCES

The second option for a Catholic medical practitioner is to ignore in his or her practice the teachings of the Church and to advise and prescribe methods of effective family planning. The Church allows so-called natural methods of family planning, for example, periodic abstinence, ovulation methods, and so on. ${ }^{1}$ In 2004, a Cochrane review of natural methods of family planning indicated that insufficient data were available to reach a definitive conclusion about their effectiveness. ${ }^{5}$ While these natural methods seem to be effective if practised to the letter, experience shows that in everyday life they have an unacceptable failure rate. ${ }^{6}$

A third option is available to Catholic practitioners living in developed countries, where there is an abundance of practitioners not limited by the Church's teachings, namely referral. However that option is very often not available in developing countries.

\section{THE VATICAN'S POSITION}

It appears that many Catholics, even practising ones, distance themselves from the teaching of the Church in their private or public life or both. In a large international poll conducted by Univision ${ }^{7}$ it was evident that a percentage of professed Catholics disagree with the Vatican with regard to its position on family planning. In addition, many of the countries with the highest Catholic populations such as Brazil, Italy, Mexico, the Philippines, Poland and even the USA ${ }^{8}$ have among the greatest prevalence of use of modern methods of contraception. 9 The findings of the Univision poll, ${ }^{7}$ namely that large number of Catholics around the world disagree privately or openly with the position of the Vatican and seem to act accordingly, might possibly trigger the Vatican to review its doctrine in this matter. The enthusiastic reception that Pope Francis received from many quarters on the first anniversary of his Papacy is indeed reassuring in this regard. ${ }^{10}$ While the teachings of the Church have not changed yet, the openness of Pope Francis and his willingness to listen and to consider some of the real problems certainly justifies cautious optimism for change, including in the area of family planning. The official position of the Church certainly continues to be unwavering, ${ }^{11}$ but there are indications that some Catholic theologians are actually in favour of a change and even predict a future revision in the teaching of the church regarding family planning. ${ }^{12}$ Furthermore, in October 2014 the Vatican convened a Synod in Rome to discuss modern-day issues related to 'the family.' A working paper has been published and its perusal reveals the very broad and far-reaching agenda for this Synod, including family planning and birth control. ${ }^{13}$

\section{CONTRACEPTION IN THE DEVELOPING WORLD}

During my career as a physician I have practised medicine in different cultures in various areas of the world. ${ }^{14}$ As I look back on my earliest experience as a 'brand new' physician, straight out of internship and assigned to a small rural hospital in Africa about 50 years ago, it is disconcerting to realise that many years later, despite so many technical advances, little has changed for the large number of people living in underserved areas. I have seen and experienced firsthand the many unfulfilled needs of these places and I now realise how difficult it actually is to fulfill these needs on a permanent basis. A major unfulfilled need in developing areas of the world is the overwhelming demand for safe and effective family planning, with contraception and sterilisation readily available.

I have worked as an obstetrician and gynaecologist in a number of hospitals in the developing world and several of these hospitals were operated by Catholic nuns. They do an excellent job, often with minimal resources and under rather primitive and difficult circumstances. In one of these places I saw a real ray of hope regarding the need for family planning in a Catholic setting. ${ }^{14}$

I was preparing to do a repeat Caesarean section on a relatively young woman (in her early thirties) who had already had several children, all delivered by Caesarean section. After the woman had signed a consent form (or rather placed a cross in the appropriate place of the form as she could not write), and just before bringing her into the operating room, one of the nuns approached me, took me aside, and said something like this: "Dr LeMaire, you know that this woman already has several children, her husband is out of work and they are very poor. Do you not think that it would be a good idea to tie her fallopian tubes so that she would be permanently sterilised? Please go and talk to her". I spoke to the patient and when I offered her tubal ligation she thanked me profusely in her own language. It then became necessary to have the patient sign an additional consent for the tubal ligation, which I thought might have presented a problem. However the nun was prepared for this situation and pulled out a separate form, which the patient marked with an $X$, and instead of placing that form into the patient's file it went into a bottom drawer of the nun's desk. These devout religious women were realistic and understood the needs of the local people clearly, as demonstrated by their humane and compassionate action.

\section{LOOKING TO THE FUTURE}

The awareness and debate on this crucial issue has recently achieved global attention with a statement published in February 2014 by the United Nations Committee on the Rights of the Child. In their publication, that Committee severely criticised the position and actions of the Vatican with regard to a number of issues. ${ }^{15}$ While the document focused mainly on other matters (including homosexuality, sexual abuse, and the rights of the child and the family, amongst others), 
the Church's position on family planning was also addressed. The Committee recommended that the Holy See review its teachings regarding family planning and contraception as they pertain to adolescents (Section F, paragraph 57a). ${ }^{15}$

As mentioned earlier, ${ }^{12}$ there are Catholic theologians who believe that a change in the teachings of the Church regarding family planning is not impossible and may actually be forthcoming. If the deliberations at the highest level of the Church during the 2014 Rome Synod ${ }^{13}$ result in 'modernisation' of the Church's teachings, these changes will be welcomed by non-Catholics and, in my opinion, by a large majority of Catholics, ${ }^{7}$ and would have a positive global impact. From a personal perspective, my hope is that this change will occur in the not-too-distant future, so that Catholic practitioners will no longer need to choose between the dilemma of following their conscience and making effective methods of contraception available for their patients, or following the present teaching of the Church and denying their patients what they want and need for planning their families.

\section{Competing interests None.}

Provenance and peer review Not commissioned; externally peer reviewed.

\section{REFERENCES}

1 Encyclical Letter. Humanae Vitae. Pope Paul VI. The Pope Speaks 1969;13:329-346. http://www.vatican.va/holy_father/ paul_vi/encyclicals/documents/hf_p-vi_enc_25071968_ humanae-vitae_en.html [accessed 16 August 2014].

2 Catechism of the Catholic Church. Part Three. Section One. Chapter One. Article 6: Moral Conscience. http://www.vatican. va/archive/ccc_css/archive/catechism/p3s1c1a6.htm [accessed 16 August 2014].

3 HowMany.org. Overpopulation: environmental and social problems. Institute for Population Studies. 2010. http://howmany. org/environmental_and_social_ills.php [accessed 16 August 2014].

4 Wise J. About that overpopulation problem. Future Tense. 9 January 2013. http://www.slate.com/articles/technology/ future_tense/2013/01/world_population_may_actually_start_ declining_not_exploding.2.html [accessed 16 August 2014].

5 Grimes DA, Gallo MP, Grigorieva V, et al. Fertility-awareness based methods of contraception. Cochrane Data Base Syst Rev 2004;4:CD004860.

6 Trussell J. Contraceptive failure in the United States. Contraception 2011;83:397-404.

7 Univision Survey. The voice of the people. http://www. univision.com/interactivos/openpage/2014-02-06/la-voz-delpueblo-matriz-1 [accessed 16 August 2014].

8 Live Science. The World's Catholic Population. 19 February 2013. http://www.livescience.com/27244-the-world-s-catholicpopulation-infographic.html [accessed 16 August 2014].

9 United Nations. Department of Economic and Social Affairs. Population Division. World Contraceptive Use 2014. http:// www.un.org/en/development/desa/population/publications/ dataset/contraception/wcu2014.shtml [accessed 16 August 2014].

10 Beard K. The people's Pope completes his first year of papacy. U.S. News. 14 March 2014. http://www.usnews.com/news/ newsgram/articles/2014/03/14/pope-francis-the-peoples-popecompletes-his-first-year-of-papacy [accessed 16 August 2014].

11 Richert SP. Pope Benedict and condoms: what he did and did not say. About Religion 23 October 2010. http://catholicism. about.com/b/2010/11/23/pope-benedict-and-condoms-what-hedid-and-did-not-say.htm [accessed 16 August 2014].

12 Maguire DC. The moderate Roman Catholic position on contraception and abortion. http://www.religiousconsultation. org/News_Tracker/moderate_RC_position_on_contraception_ abortion.htm [accessed 16 August 2014].

13 Synod of Bishops. III Extraordinary General Assembly. The Pastoral Challenges of the Family in the Context of Evangelization. 2014. http://www.vatican.va/roman_curia/ synod/documents/rc_synod_doc_20140626_instrumentumlaboris-familia_en.html [accessed 16 August 2014].

14 LeMaire WJ. Crosscultural Doctoring. On and Off the Beaten Path. 2012. http://www.smashwords.com/books/view/161522 [accessed 16 August 2014].

15 United Nations. Committee on the Rights of the Child. Convention on the Rights of the Child. Concluding Observations on the Second Periodic Report of the Holy See. Document CRC/C/VAT/CO2. 2014. http://tbinternet.ohchr.org/ Treaties/CRC/Shared\%20Documents/VAT/CRC_C_VAT_CO_ 2_16302_E.pdf [accessed 16 August 2014]. 